\title{
"To Make the Four Hundred Million Move": The Late Qing Dynasty Origins of Modern Chinese Sport and Physical Culture
}

\author{
ANDREW MORRIS \\ California Polytechnic State University
}

There is no athletic movement in China. .. . This is not because the Chinaman is lacking in ability, for, on the contrary, he has a much better head (and heart too) than the Japanese, but because unity of purpose or endeavor or progression of any sort is foreign to China. . . . It is really only using up good space to discuss further the Chinaman's relation to sport. He has none, and, from the present outlook, it will be many years before he acquires any.

-Caspar Whitney, in Harper's Weekly, $1898^{1}$

Just as our women [swimmers] dominate you now, so will our men dominate you in four, five, six years, and so too will we dominate you in world economics.

-Zhou Ming, Head Coach, PRC National Swim Team, $1997^{2}$

There is little doubt that, after a century's exposure, Chinese have absorbed and understand quite clearly the greater meanings of the realm of sport-the connections between competitive athletic endeavor, imperialist bluster, and economic standing in the world community. This article is an exploration of the late Qing Dynasty origins of this modern global culture of physical culture and sport.

China boasts a rich history of physical culture - from the archery of Confucian scholarly culture, to the kickball games used in military training, to aristocratic polo and golf games, to ice skating pageants performed for imperial audiences, to the diverse and popular histories of Chinese martial arts. Depending upon how broadly one wants to define the term, the existence of Chinese "physical culture" can be dated back to the Shang Dynasty (seventeenth-eleventh centuries BCE), when oracles inscribed records of dance, swimming, riding, and other physical forms related to hunting or ceremony onto cattle bones and

I would like to thank Joseph Esherick, Paul Pickowicz, Julie Broadwin, James Cook, Josh Goldstein, Michael Chang, and two anonymous CSSH reviewers for their many helpful comments on this piece. 
tortoise shells. ${ }^{3}$ Not quite "sports" as we would understand them today, these and subsequent Chinese physical genres were significant in many different and distinct imperial contexts, including notions of martial manhood and conquest, aristocratic privilege, local or popular flavor, religious and/or imperial ritual, and cosmological and calendrical patterns. ${ }^{4}$

The modern physical culture brought to China in the late Qing Dynasty and known as "tiyu" (physical culture, physical education, or more literally, "bodycultivation") was a totalizing and systematic ideology of personal behavior and its physiological implications, which was invested with definite ideals of the relationships between the individual and the national body, and between the individual body and personal character. In short, the modern tiyu was to this diverse body of ancient physical cultures what the new nation-state was to the old imperial construct of the Tianxia ("All Under Heaven")—a break, brought in the name of unforgiving and violently intolerant international standards, commerce, and engagement.

Allen Guttmann's book Games and Empires surveys the diffusion of the Olympic Games and modern sports like cricket, soccer, baseball, basketball all around the globe. In his introduction, Guttmann raises the question of whether sports are an instance of "cultural imperialism." His concluding chapter, which explains these sports as instances of ingenious cultural borrowing, dismisses this classification, instead preferring to emphasize the communitarian and liberating aspects of these physical activities. ${ }^{5}$

Guttmann's work provides a valuable survey of modern sporting history, and the important models he cites certainly help to situate these histories of transnational cultural flows and influences. However, his basic frameworks are much less useful in seeing what these physical forms mean to the peoples who adopt them. That is to say, it is clear that such sports are spread by "cultural imperialists" eager to civilize or Christianize heathen idolaters the world over. Just as clear is the pattern in which they are adopted and adapted by indigenous groups, who identify their own specific social or political uses within the original forms. However, the present paper aims to move beyond this important, but basic, level of analysis. Instead, it attempts to identify which aspects of modern physical culture appealed to reformers, educators and nationalists of the late Qing Dynasty.

The origins of modern sports and physical culture in China-the training regimens and competitive activities described below-were almost always restricted to China's cities. There, educational reform, the presence of a growing middle class, and (usually) the presence of eager foreign missionaries combined to create an environment in which sports could flourish and become an important symbol of status, masculinity, and nationalism. However, by the time of the fall of the Qing Dynasty in 1911, modern sports were hardly just an isolated treaty-port phenomenon in China. Rather, modern tiyu had already become a cultural realm in which those in commercial and political centers all over 
Chinese territory now could share. The popularization of social Darwinian thought over the last decade and a half of the Qing Dynasty had set the stage for the rise of these competitive sports forms. By then, it was no great leap at all to adapt to the Chinese setting the games and ideologies brought by generous teachers of the imperialist West and Japan. Banished were the physical culture forms of the imperial age; once these new forms came to China, it was a whole new ballgame.

\section{ON STRENGTH: LATE QING NOTIONS OF PHYSICAL FITNESS}

Many historians in the PRC today see the beginnings of modern Chinese physical culture in the yangcao (Western drill) taught in some of China's modernizing armies in the 1860s and 1870s. ${ }^{6}$ I do not find this a useful starting point, however, as military drilling is still quite far removed from the comprehensive ideologies of physical and mental fitness that lay at the root of modern Chinese tiyu. Instead, a useful search for the roots of modern Chinese physical culture must begin with a study of late Qing self-strengtheners, reformers, and revolutionaries who, alarmed by imperialist advances over the Chinese empire, looked to individual bodily strength and physical fitness as the key to larger issues of national and racial survival.

The late Qing crisis was not necessarily the moment when Chinese first began to formulate connections between individual bodies and the welfare of the larger national community. For millennia, the imperial social order rested on the person of the Confucian scholar-gentleman. The gentleman's worthiness of this position in turn was based on his mastery of the Six Arts, two of which (archery and chariot driving) were affairs of the body. The martial ethos, another realm in which wits and physical might were combined, was a cardinal element of the imperial heritage, embodied by heroes like Yue Fei, valiant twelfth-century defender of the Song Dynasty against the "barbarian" Jurchens of the Manchurian Jin state. Recent work by Angela Zito also illustrates the importance of the human body in state rituals designed to "center" the Chinese imperial state, allowing it to "make the triad with heaven and earth."7 These three brief precedents may illustrate how late Qing notions associating the individual body and the affairs of the empire did not in themselves present a radical break from traditional imperial precepts.

The "wealth and power" reform atmosphere of the late nineteenth century, which gave rise to ideas that can be seen as part of a "modern tiyu ideology," can also be seen as firmly based in Confucian tradition. The rigorous concentration on moral reform and statecraft - a program which later lent itself easily to new ideas of the body and strength - came from concerns still rooted securely in the classical Confucian canon. ${ }^{8}$ After the disasters of the Second Anglo-Chinese War and the Taiping Rebellion, the "self-strengthening" reformers' 1860s plans for military modernization also provided fertile ground for notions of physical strength and the nation. The reformers, too, envisioned 
their proto-tiyu plans as merely part and parcel of the Confucian concern for the state and the military. ${ }^{9}$ And Benjamin Schwartz has described the $1880 \mathrm{~s}$ search for "the techniques of wealth and power," the avenue by which modern physical culture entered into Chinese reformist thinking, as a revived commitment to "that Legalist vein of Confucian thought which had stressed the compatibility of wealth and power with Confucian values."10

Yet it took more than these indigenous traditions to get to a position that could accommodate the modern forms of physical culture brought by Western and Japanese imperialists just years later. The crucial link with the late Qing turn to matters of the individual body and racial-national strength, quite simply, was the Chinese discovery of nineteenth-century Western writings on evolution and human progress as a deciding factor in the course of history.

The mid- to late-nineteenth-century trends of practical and morally relevant research (as opposed, by many, to kaozheng evidential scholarship), selfstrengthening, and the search for techniques of wealth and power were all important and necessary blocks in the foundation of this later awareness of the modern role of the individual body. However, the powerful discourses on the interrelatedness of moral, intellectual, and physical education, or on physical preparedness and competition in a ruthless world, never could have arisen in Chinese reformist circles without Spencerian and Darwinian nudges. ${ }^{11}$ The progressive sociological and scientific teachings of these latter-day Western sages made much sense to Chinese reformers who were at the end of their collective rope and hunting determinedly for innovations that would allow China's ancient heritage to survive the ominous crises of the late Qing.

The disastrous Sino-Japanese War of 1894-95 was the final straw that brought Chinese reformers and revolutionaries to an acceptance of Western ideas of the supremacy of the individual body. In a world narrated by Spencer and Darwin, the individual self was now a self-enclosed container. The self which every person was, was now seen to contain within itself a trainable and improvable whole, whose condition carried critical importance for the welfare of the greater community. Here, mind and body were understood as separate and independent, but still mutually influential entities. The self also contained a "morality," a quality that was understood to be a socially relevant force intervening between the affairs of the mind and one's corporeal habits and behaviors. And this new self was graciously welcomed to a late Qing world where reformers for decades now had decided, on thoroughly Confucian terms, to use new practical and forceful ways to strengthen the nation.

\section{FROM A PHYSICAL EDUCATION TO THE MARTIAL SPIRIT}

Most scholars agree that the earliest Chinese usage of the phrase tiyu, which now signifies the categories known in the West as sports, physical education, physical fitness, and recreation, came in famed writer-translator Yan Fu's 1895 essay "On Strength." 12 Yan used the phrase in the context of his discussion of 
Spencer's formulation of the holy trinity of moral, intellectual, and physical education, and this origin of the term is important for several reasons. Schwartz describes Spencer's world, in Yan Fu's formulation, as consisting of "energy, dynamism, struggle, self-assertion, and the fearless realization of all human potentialities on ever higher levels of achievement." Yan understood this struggle in terms of Spencer's nation-society, where the duty of the individual is "above all a commitment to the survival and growth of the social organism of which he is a part." 13 This was the context in which Yan's "physical education" or "physical culture" was relevant. His tiyu did not connote a given set of physical activities or even ideologies, but was an all-encompassing construction representing the importance of the individual body in a new China fit to survive in modern times.

These Spencerian connections are also significant in that the earliest appearance in Japan of the phrase taiiku ( $>$ Chinese tiyu) was in documents explaining the new Meiji educational system of 1872, also via contemporary translations of Spencer. ${ }^{14}$ It is my guess that Yan Fu knowingly borrowed this term from Meiji-era Japanese writings on ideas of taiiku physical culture and society. Whether this is true has never been established by historians in this field. Still, it is very easy to imagine, given the heavy debts owed by the late Qing Chinese tiyu community to Japanese adaptations and translations of European physical culture in general.

Tiyu to the late Qing reformers signified any general program that would allow the people of China to develop their bodies and the latent martial virtues that would be unlocked by this new personal strength. In "On Strength," Yan writes:

Today, if we want to talk about the wealth and power of nations, the basis must be the physical strength of the people ... if we look at the lessons left us from Chinese and Western history, of the fifty to sixty nations that exist on the five continents today, there is not one that did not arise out of this [physical strength]. Greece of the Zhou [Dynasty], Rome of the Han, the Turks of the Tang - these dominant groups of each age have all grown to be strong and beautiful, able to withstand suffering and capable in war, ruling over their era. ${ }^{15}$

By locating China squarely within the powerful legacies of Western antiquity (or, in fact, vice versa: Greece of the Zhou, Rome of the Han!), Yan posed the new connotations of physical and national strength as a universal common sense. Indeed, it must have seemed as such to intellectuals raised on decades of talk of practical, immediate, Western-modeled reform.

Once Yan made these bold claims to an immediate and straightforward solution for China's problems of weakness, scarce was the reformer who did not weigh in with his own suggestions in the field of physical training. The hotblooded reformist martyr, Tan Sitong, saw direct connections between a society's "dynamism" or "love of movement," and the status of that nation on the world stage. Hao Chang has written on Tan's admiration of Western-style so- 
cial progress, and on his use of organic metaphors of the human community bonded and charged by an electricity like that of the human nervous system. ${ }^{16}$ Convinced of the primacy of movement, Tan wrote about the need "to make the four hundred million move (dong)." He explained that "Western hegemony over the five continents comes from their love of movement," and concluded that "China's fall will be mourned because of its passivity [jing]."17

The influential intellectual Liang Qichao felt just as strongly about this need for a new physical culture. In his 1902-03 series "On the New Citizen," Liang wrote on the calamitous legacy of the weak Chinese body, which had everything to do with the absence of concepts of progress, public morality, and duty in China. ${ }^{18}$ Liang saw "competition" ( jingzheng) as "the mother of evolution" (jinhua zhi mu). Only by keeping abreast of this constant Darwinian competition could an individual or nation survive, and this was possible only by keeping physically strong (as well as morally and intellectually strong, which would directly follow).

Liang even came to imagine the constant contest of life in the modern age in terms of physical competition, describing it thusly: "Yesterday B beat A. Today $\mathrm{C}$ beats $\mathrm{B}$. Tomorrow A still has to beat $\mathrm{C}$. All are proud, all are jealous of the others, but all still teach the others. It is like a horse race, or a footrace, or a boat race." ${ }^{19}$ In "On Martial Spirit," Liang went so far as to advocate specific types of physical training. He maintained that there was not a single European nation that did not aggressively push calisthenics, fencing, horsemanship, soccer, wrestling, marksmanship, swimming, and boat races among their citizenry, and identified China's weakness and lack of martial spirit as a result of the absence of such programs of physical competition. ${ }^{20}$

The writings of future Republican military hero Cai $\mathrm{E}$ were also important in proving the demand for a new Chinese physical culture. Writing in 1902 in Tokyo, Cai's thoughts were seen as important enough for Liang Qichao to include in the first issue of his journal New Citizen. In a long piece serialized over four issues, Cai coined the phrase "militarized citizenship" ( jun guomin) during his discussion of the military training that Chinese would have to undertake in order to strengthen their bodies. His article "On Militarized Citizenship" made Yan Fu-influenced appeals to antiquity and the lessons of military strength.

Sparta's heroic domination of Greece, Rome's sway over Europe, the Mongolian Tartars' trampling of the Orient, the Turkish barbarians' defeat of the Roman race-none of these [peoples] had what we would call outstanding knowledge, but their bodies were strong and ferocious, so that they could withstand the most intense winters and the fiercest summers, wind and rain, hunger and famine, and not even think anything of it. ${ }^{21}$

Cai also looked to the contemporary world for examples of this militarized identity, seeing the origins of the United States' world standing and its robust Monroe Doctrine in the patriotic and martial-tinged activities featured in American elementary schools. ${ }^{22}$ Still, Cai felt that these historical achievements were 
not out of reach of the Chinese people. All it would take was a total commitment to this "militarized citizenship," this ideal of physical strength as a defining characteristic of the new Chinese citizen. Cai continued:

With regards to physical fitness, our encouragement will not be credible until we come up with something tangible. If it is boat racing, fencing, footraces, hitting balls, swimming, firing guns, wrestling, horsemanship, archery, or wheeled racing (using bicycles to race), the winners have to be rewarded with something of value. Even if it means getting some famous scholar to give his encouragement to a winning team, this will add to the reputation [of the physical fitness movement], and before long it will become a custom. ${ }^{23}$

Cai's formulation of "militarized citizenship," complete with his very concrete suggestions for breeding this quality in China's citizenry, soon became one of the cornerstones of late Qing physical culture philosophy.

If Cai's model of "strong citizens, strong nation" is not blinding in its originality, the syntax of his formulations of "militarized citizenship" and "militarized citizenship education" is still very instructive. Although junguomin could be read as junguo min, and translated as "citizen of a military nation," I prefer the more dynamic reading jun guomin ("militarized citizenship"). Jun (militarize) served for $\mathrm{Cai}$ as a transitive verb, describing an active militarizing process. In this model, China's new citizenry was targeted as the direct object of these competitive activities that could transform them into "militarized" citizens truly prepared for the struggles of the twentieth century.

Later that same year, Jiang Baili, a cadet in the Army Officers' Academy in Japan, published another important article on this topic in New Citizen. Entitled "Militarized Citizenship Education," the piece was part translation of Japanese materials and part Jiang's own reflections on the nature of the nation and society as an army writ small. Prefacing his thoughts with the observation that the "commercialized" nations of the world were all established through "commercial competition," Jiang saw the military as the institution most capable of training a disciplined and rational citizenry. ${ }^{24}$ Jiang proclaimed that he would "rather be a martial fool than a literate weakling," and looked to a new educational system that would provide Chinese society with this militarized spirit. The "citizen factory," - the "origin of national ways" that the modern school was - would have to provide a strong emphasis on several forms of calisthenics, outdoor games, competitions, and marches. ${ }^{25}$

This model of the "militarized citizen" soon became an influential one, with other writings on this subject appearing in influential journals published by Chinese students in Japan, such as Hubei Student and Zhejiang Tide. ${ }^{26}$ While taking a more explicitly military-centered position than Liang Qichao, this work on the militarized citizen shared much in common with Liang's writings. Here, too, their system of grueling and competitive physical activities was imagined as an effective regimen that would work wonders on the physical strength, and also the national commitment, indeed the very citizenship itself, of its subjects. 


\section{WOMEN'S PHYSICAL FITNESS: RACE AND NATION}

To this point, I have left unquestioned the category of "nation," which was used to justify the physical culture philosophies and programs described above. At the heart of Chinese imaginations of the nation that would be fortified by this new drive for tiyu was the notion of race. In twentieth-century China, race and nation have never been easy to define independently of one another, entangled as they are in the phrase minzu, which I choose to translate as "nation-race." 27 Minzu is a complicated term, taken from the Japanese minzoku, and heavily laced with both national and racial meanings. ${ }^{28}$ This etymological vaguenessits position in between ideas of a modern citizenry and a primeval race of descendants of the Yellow Emperor, in between Western scientific ideas of race and a Chinese community covering the realm "All Under Heaven"- - was in fact a key to the popularization of this term. In the minzu, race could be nation and vice versa. The race could be strengthened by the modern constitutional trappings of the nation-state, and the nation emboldened by claims to a common and glorious racial fountainhead.

Significantly, this important category of the "racial" Chinese nation entered the physical culture dialogue via the great emphasis placed on the condition of women's bodies. Like the general discourse of physical fitness and preparedness and the state of the nation, this discussion of race and Chinese women began with references to Greek and Roman antiquity. Yan Fu described with great admiration Spartan programs of physical training and the public jin-meng-nazhi-an (gymnasium) where women could train their bodies. ${ }^{29}$ Liang Qichao's "On Martial Spirit" also praised the universal physical training programs of ancient Sparta, where women and men, old and young, were all included. ${ }^{30}$

This concern for women's bodies and health was mostly an extension of anxieties about the Chinese racial stock, and the need for women to preserve the race by giving birth to "strong and stately infants." ${ }^{11}$ These concerns were often articulated via the condemnation of harmful Chinese customs that weakened women's bodies, like the practices of early marriage and footbinding. This latter custom was a favorite target of concerned missionaries, and then of lateQing Chinese reformers. Footbinding was unanimously condemned and essentialized at the end of the nineteenth century as an ultra-villain in the history of the Qing Dynasty's decline into "national shame." Where modernists, Chinese and Western, have long taken these critiques at face value, Dorothy Ko has shown that these abolitionist writings have to be seen as "colored by China's search for a virile identity under the traumas of imperialism." 32 And not only was this male textual attention to footbinding motivated much more by national than female/personal narratives, it also failed to take into account the fundamental un-"Confucian" nature of the practice. Indeed, as Ko has pointed out, "literary production was the antithesis of what footbinding was supposed to be about." 33 
These niceties, however, were not enough to stop the chorus of abolitionists who now saw boundfoot women as the chief cause of the Chinese nation's lethargy and enervation. Benevolent male reformer after benevolent male reformer registered ringing condemnations of the depraved, crippling custom of footbinding. Zhu Zhuang, in an article entitled "On the Harm Done by Stagnancy in Women's Education," gave this explanation:

Mothers with bound feet cannot exercise, so their arteries get stopped up and they are all sick. All the sons and daughters they produce are emaciated and weak, dizzy and likely to die young. Most never live as long as Heaven intended them to, and if they do grow up, they are just more sick people. This is why people of our nation are ridiculed as "sick men" (bingfu) by all the nations of the globe. ${ }^{34}$

Another author, perhaps inspired by this logic, made a similar point:

Of the women of our nation, there is not one who does not have a disease of the blood or spirit, and these illnesses are never cured well. So the sons and daughters whom they bear are polluted by heredity and this diseased body. When they become adults, they will never grow to be strong and healthy either. And each generation just gets weaker than the one before it. This is why Westerners laugh at us, and even have a name for us, the Sick Man of the Orient [dongfang bingfu]. ${ }^{35}$

In 1905, Yuan Shikai, Governor-General of Zhili Province and Commanding General of the North China Army, wrote a typically unimaginative and forcefully argued piece titled "Women are the Mothers of Citizens" for a Japaneserun newspaper in Beijing. Yuan first tried to draw his readers in with a statement upon which all could agree: "talented people are born of humans, not born of men but born of women." The authoritative Yuan, never one to beat around the bush, quickly came to the crux of his argument and worry:

Of course, strength is good, and weakness is bad. But [Chinese] women today are all of weak constitution. Of course, civilized is good, and obstinacy is bad. But of [Chinese] women today, there could be only a few who are civilized, while at least nine of ten are just obstinate. If you think that these women, weak and obstinate, are going to breed children who are strong and civilized, this is going to be extremely difficult.

The China of Yuan's dreams would be one where women's feet were unbound, allowing them to take part in physical exercise and go to school. There, they could finally learn about the "science of the strong nation and strong race," a body of knowledge that Yuan understood as no less than "the universal principle of the world, the universal rule of evolution." Finally, Yuan closed his piece with an emotional, if painfully condescending, call:

Without women, how can we have citizens? If we want to cultivate citizens, we must first cultivate women. If we want to uphold and respect the citizen, we must first uphold and respect the woman. Citizens, oh, citizens! And who produces citizens? Women! Once more I stand and sound my call three times: Women are the mothers of citizens! Women are the mothers of citizens! Women are the mothers of citizens! ${ }^{36}$

A columnist for the daily Sigh of the People imagined a similarly direct and instrumental correspondence between the new healthy Chinese woman and the 
nation. In his article on an athletic meet held at the Shanghai Girls' Middle School, the unnamed author summed up in five sentences the actual games and dancing events actually performed at the meet. However, four times as much newsprint was devoted to his extended ruminations on the connections between healthy women and a nation that could finally be accomplished both in literature and in politics. ${ }^{37}$

The logic was simple. Everything about the Chinese nation was weak and feminized in the imperialist narratives of the late nineteenth century. Chinese women were easily isolated as the weakest of the weak, the most stagnant, sluggish, passive - the "most Chinese" of all. All two hundred million of them were thus identified, with the rapier point of scientific wisdom, as the root of the problem. ${ }^{38}$ The late Qing reformist fascination with the objective "health" of Chinese women's bodies appeared as they used a new and unchallengeable biological authority to present Chinese women's weakness as a dangerous but solvable racialist cause of the weakness of the Chinese nation.

The ability of these vocal and influential male reformers to convince their fellow countrymen of the importance of female exercise did not constitute the entire solution to this crisis, however. The new Chinese experts, educated in Japanese and/or Western physical education theory, were also entrusted with the task of designing gender-specific forms of training appropriate to girls' and women's distinct physiological and psychological needs. As one educator pointed out, girls liked imitating their mothers, playing with dolls and games that were "dainty and cute." Boys on the other hand liked playing with knives, drums, and air guns, and joining in games that were "active and explosive." 39

Thus, the model that Tani Barlow refers to as "the imperialists' sex binary" 40 was being used by these educators to posit boys as the true makers and shapers of the new China, as opposed to the domestic role that they now hoped to "prove" was appropriate for women. One article on physical education curriculum design reminded teachers about "the natural differences between the two sexes," which were as follows:

What boys' spirits have more of than girls' is vigor, courage and strength. But the qualities such as sweetness, beauty and emotional range are not as developed [in boys] as in girls. Girls lack daring, tolerance and courage. Their bodies are always very different from boys' as well. From the skeleton, tendons and flesh, to the inner organs and all the body's systems - [in girls] they are all soft and weak. Their capability to resist is weak. ... [Girls] are not equal in vigorous activities. ${ }^{41}$

Or, as Cai Wensen's translation of Japanese education expert Itô Yonejirô put it, "Girls' nature is conservative. Boys' nature is forging, enterprising, active. Girls are rooted in emotion, their main apparatus. Boys are rooted in the will, and are active." 42 Physical education now had to be a scientific method of separating out male and the female qualities and needs, and emphasizing them in students of the appropriate gender through careful training. Only then could China achieve a society that met these requirements of the modern age. 
To this point I have presented the field of women's physical education and fitness as an exclusively male domain, an ironic reproduction of the "Confucian" system of male domination that these reformers felt existed. There were, however, women making themselves heard about the need for women's physical education programs as well. Many of these women used the trope of the healthy Western woman, utilized and implied so often by Chinese men in their criticisms of weak Chinese women, to their advantage. In 1896, an author calling herself "Pained Woman from Yuanhu" wrote an article for the Shanghai missionary newspaper A Review of the Times on the subject of footbinding. In condemning this custom, one which she felt was "no less cruel than death by fire or the ritual drowning of women," the author appealed to the modern specter of exercise and physical fitness:

Bound feet make one sigh with distress from morning to night, as the discomfort of our unhealthy spirit and blood, and our misery, are always there. What makes this even more difficult is that it is not easy at all for us to exercise. When one compares us with the women of the West, so free to move wherever they wish, how could our situations be so far apart, as far apart as heaven and earth? ${ }^{43}$

This perceptive author also dangled the equally bewitching promise of industrial efficiency before her audience, hinting that there were many factories which could use a female labor force freed of this painful footbinding custom.

Xiaomei Chen has coined the term "Occidentalism" to describe the practice whereby "constructing its Western Other [allows] the Orient to participate actively and with indigenous creativity in the process of self-appropriation, even after being appropriated and constructed by Western Others." 44 What differentiates Chen's work from other models of the appropriation of colonialist language and ideologies, and what makes it so relevant to this case at hand, is the space it provides for dissidents to critique their "own" government via these imported terms and technologies. When the "Pained Woman from Yuanhu" asked Chinese men to explain the miseries that Chinese women had to suffer while Western women were so "free," she created a perfect instance of what Chen calls "anti-official Occidentalism." Chen explains how this important mode of discourse allows "Oriental" dissidents to design powerful discourses by explicitly "using the Western Other as a metaphor for political liberation."45

This is precisely the Pained Woman's strategy. Perhaps most "dissident" was her challenge to the very legitimacy of the Qing court that allowed the custom of footbinding to continue. In concluding her piece, the author demanded that if any imperial officials of the third rank or higher allowed their daughters' feet to be bound, that they be held personally responsible and punished, their positions stripped from them, and labeled as members of the "mean" (jian) classes! 46 The Pained Woman's imaginings of free and mobile "Other" Western women allowed her to call attention to the status of women in Chinese society, in the same hegemonic terms used by male intellectuals. But her clever use of their modernist gaze-which also happened to accommodate this critical 
space-turns women's tiyu from a category subservient to the national-racial good into a category of women's liberation.

A woman named Chen Xiefen, writing in 1903 for the Shanghai journal Women Studies, utilized other unique arguments to posit the importance of women's physical fitness. First exhorting her two hundred million female compatriots to see that "without physical fitness one cannot achieve beauty," Chen then moved on to more weighty Spencerian terms. Citing the common sense that a physical education was absolutely intertwined with any moral or intellectual education, Chen declared that "any evil opposition to physical fitness [tiyu] must be understood as an opposition to morality [deyu] and wisdom [zhiyu]!" Finally, Chen completed her argument by citing physical strength as a prerequisite for women's ability to fulfill the traditional Chinese motherly task of educating sons at home ${ }^{47}$ Chen's appeals for women's say in their own physical fitness and wellbeing were thus phrased in terms that male reformist intellectuals could never dispute. While toeing the Yan-Liang line that national strength depends on women's physical strength, Chen also brought to bear the orthodox Confucian ideal of the wise and virtuous mother. In arguments like Chen's, women's liberation came to be associated with national liberation, ${ }^{48}$ making the powerful point that the present late imperial order prevented women from ever truly aiding the nation.

This image of the (newly) liberated, strengthened, and invigorated young woman saving the Chinese nation was a powerful one. But it could become even that much more meaningful when actually enacted in real life. An athletic meet held in mid-1911 at the Middle/Elementary Girls' School in Shanghai included, amidst the calisthenics and dance routines, events listed as "Recover Sovereignty" and "Seeking Donations for the Northern Jiangsu Province Flood." After the second of these "events," many spectators were apparently so moved by the new female dynamism and national initiative that they reportedly "untied their purse strings to make their donations." 49

In these ways, the male-dominated late Qing discourse of physical strength was mediated and appropriated by women who worked to keep the realm of women's tiyu open to women's own ideas of what their healthy bodies represented. But the larger idea-that a strong and healthy society and nation would correlate directly with the physical strength of its people (of course bred and nurtured by women) - was virtually unassailable by the early 1900s. From their unique position as keepers of the racial key to strength and modernity, women came quickly to occupy a major place in the physical culture discourse. The last decades of the nineteenth century saw new trends in the Qing Dynasty of socalled "practical" endeavor and modern methods. These developments were then topped off by Spencerian and Darwinian notions of society and race, energy and dynamism, and the newfound ability for the individual to make his or her discrete contribution to the whole. As a result, these notions of the utility of the healthy and fit individual body, born and bred by women, as Yuan Shikai 
reminded us, provided the background for the whole of China's modern tiyu enterprise.

\section{GOOD LAUGHS AND HARD KNOCKS: SPORTS IN THE LATE QING}

"Competetion is the life of trade." "All is fair in love and war." "To every action there is an egual and opposite reaction." "The spirit of contest is the joy of exercise." "Evolution and man." "The ying and the yang." These and many others are fragmantary statments of a great and universal truth. They are expression that have come to us from various fields of observation and experience they are all related because they have to do with a great principle the meaning and extent of which the world has not yet been able to state nor even to conceive in its entirety. ... A manifestation of one phrase of this great principle among men is included in the word "athletics."

-Tientsin Young Men, $1906^{50}$

In the quote that opened this article, we saw how a knowledgeable Western observer like Caspar Whitney, resident sporting expert at Harper's Weekly, found the athletic to be a realm totally "foreign" to Chinese culture. However, if we are to believe the young Chinese author quoted above (and I have found no reason not to) then this gives us a very different picture of the status of modern sports in China by 1906. As the anonymous author above points out, modern "athletic" culture in fact had become perfectly commonsensical to many in China- a universal truth no less significant than any uttered by great men like Adam Smith, Isaac Newton, Walter Camp, Charles Darwin, or even Laozi. In this section, I will outline the introduction of this culture of sport into Chinese schools and urban settings during the last two decades of the Qing Dynasty, a process that had momentous effects on the development of a modern Chinese physical culture in the early years of the twentieth century.

It is difficult to identify exactly the earliest presence of "sporting" activities and ideologies in China. Some point to the experiences of the 1872 Chinese student mission to Phillips Andover Academy, and the outstanding achievements in that most American of endeavors, baseball, as the dawn of sport in China. A "Chinese Baseball Team" organized at Phillips included Tang Shaoyi, future Qing minister and Republican Premier, Zhan Tianyou, the famed railroad engineer, and Liang Cheng, later Qing Ambassador to the United States. The diamond achievements of these notable men and their Chinese Phillips teammates qualify them in many minds as progenitors of the sports movement in China. ${ }^{51}$

Missionaries working to spread sports and the Good Book decades later claimed that there had been missionary-organized sports meets in "the interior" of China as early as $1885 .^{52}$ Other scholars have pointed to overseas Chinese returning from Southeast Asia-who brought back to their homes (especially Meixian County, Guangdong Province) rubber soccer balls and their zest for the game that they had learned in colonized Southeast Asia-as Chinese sporting forebears. ${ }^{53}$ Meanwhile, Wu Wenzhong, grandfather of the Chinese field of tiyu history, has judiciously identified the first modern sporting com- 
petition in China as a meet held at St. John's University in Shanghai, organized by a Canadian missionary named S. E. Smalley in $1890 . .^{54}$

There is little question, however, about the source of the largest and most lasting contribution to Chinese sport-the Young Men's Christian Association. A fine explanation of the proselytizing mission of nineteenth-century America comes in Reginald Horsman's work Race and Manifest Destiny. Horsman demonstrates that politicians and intellectuals joined common missionaries in hoping not only to spread the Christian faith, but indeed to recreate the superior "Anglo-Saxon" American society of free trade, democracy, liberty, republicanism, and science, over all of God's creation. ${ }^{55}$ As influential as it eventually became, the YMCA was merely the latest group to "follow the sun" westward and take as its mission the spread of this civilizing culture to "that Asia in which their first parents were originally planted." 56

The YMCA's timely emphasis on physical fitness in the Darwinian world of the nineteenth century was surely one of the reasons for its great success, first in the West and then elsewhere. In China, it also likely did not hurt that the YMCA took as its guiding symbol a "three-self" formulation of the complete individual healthy in body, mind, and spirit. This formula would clearly have dovetailed perfectly with the Spencerian ideals made so influential by Yan Fu. Another blessing was that the YMCA Chinese mission was undertaken just as Chinese ideals of a modern physical culture were beginning to coalesce and take shape. The YMCA quickly took advantage of the power of this realm of Anglo-American sport, co-opting and giving solid Western-based definitions to these new Chinese imaginings of a physical culture to train their bodies, race, and nation. The first YMCA in China was founded in Tianjin in 1895. There, and in other locales like Hankou, sports quickly became a primary focus of the YMCA's mission to spread Western notions of the relationships between the individual body, spirituality, and society, and by easy extension, the state of the Chinese nation.

The YMCA was not the only missionary group active in promoting the muscular Christian ideal in China at this time. In fact, Shirley Garrett's statement that "without question the YMCA was the founder of modern physical education in China" 57 is much more problematic than she might believe. Other missionary movements had similar programs and visions for China's young men. For example, in 1895, British missionaries built a ball field on the grounds of a church in the Lahu tribal village of Nuofu, near the border of Yunnan Province and Burma. ${ }^{58}$ Canadian missionaries at St. John's University in Shanghai, and British (Anglican and Presbyterian) and American (Methodist) missionaries based throughout Fujian Province also shared track and field and team sports with their pupils in the late 1890s. ${ }^{59}$

Nor were these Anglo-American sports the only significant forms of modern physical culture being spread throughout late Qing China. German- and Swedish-style gymnastics and military calisthenics, which arrived in China via 
Japan at the turn of the century, formed another modern physical genre. Known as ticao (literally "body-drill"), by the last decade of the Qing these exercises were part of the national school curriculum. Such programs sought to inculcate in their participating subjects a physical discipline and constant mental awareness, qualities necessary for the population of a nation facing imperialist aggression. Gymnastics and calisthenics constitute an interesting field of inquiry in China. The form of physical fitness initially recommended in the late Qing education reforms, ticao programs, also provides important insight into the Japanese influence in late Qing society. This form also proved to be more amenable to women's participation than were team sports at this time. ${ }^{60}$ Yet for reasons of space, I will not discuss here the career of late-Qing ticao, instead sticking to the Anglo-American ball games and track and field sports which brought a focus on teamwork and sportsmanship to physical culture.

Team sports' rational and self-conscious modernity made them much more suited for China's national era. Their measurements, times, physical and behavioral boundaries, rules and regulations could teach their participants the rules of industry and organization so crucial to the modern age. ${ }^{61}$ The sporting myths of free movement and "natural" motions fit perfectly into modern notions of egalitarianism, a necessary element of any serious national ideology. Finally, team sports were understood to be of vital relevance as make-believe Darwinist struggles that could cultivate the competitive instinct so necessary for survival in the modern world. This new sports tiyu was clearly more than a collection of mere "games" to be "played"; any serious treatment of this realm has to recognize the vital link that these activities represented between the sporting individual and the Chinese nation.

If the YMCA's claim to exclusivity in the Chinese physical culture world does not necessarily hold water, the organization must still receive credit as the most illustrious, and best organized sporting enterprise-and the most thoroughly committed to historical record-of the late Qing and early Republic. The general proselytizing mission of the YMCA in China will not be discussed here; instead, I am more interested in what the sporting component of that mission can teach us about efforts to change China by changing the bodies of its young men. Christian manhood was the prescription delivered by these medics of personal and national health. Not a single one of these missionaries imagined that China would ever be ridiculed as the "sick man of Asia" after they were finished training, building, and perfecting the new Chinese man.

The great efforts put into physical training, and the faith that this training could bring about "the uplift of mankind and the furtherance of the Kingdom of God,"62 cannot be underestimated. In 1911, of the thirteen nations lucky enough to host YMCA missions, only three (China, Brazil, and Mexico) had staff working specifically as "Physical Directors,"63 and this selectivity likely says much about how YMCA officials hoped to make their presence felt in China. Late Qing-era sources on YMCA physical culture are based almost totally 
in Tianjin (and, after 1908, Shanghai), and demonstrate clearly these missionaries' aim of building a Chinese nation and society along normalized AngloAmerican lines. In almost every way, the YMCA sporting programs were conceived and designed to bring China and its young men into the world of healthy, sporting, hard-working, and modern nationhood.

For these goals to be met, the Chinese male body had to be brought into the realm of Western reason and discipline. If the Chinese reformers described above saw the Chinese female body as the key to a strong Chinese nation-race, the YMCA was more concerned with designing and building a new and strong Chinese man. ${ }^{64}$ In the missionary project, women's physical education and physical fitness were emphasized, but as part of a separate realm of proper, expressive dances and "soft calisthenics." The YMCA's sports, on the other hand, were designed by and for men, who were expected to pilot the nation-states of the modern era.

M. J. Exner, Physical Director of the Shanghai YMCA, explained simply that the goal of sports was "to give to the young man a strong body, a good stomach, a vigorous brain, a steady nerve, physical courage and right physical habits, an efficient life being the end sought." ${ }^{65}$ A Chinese convert was more specific about the exact stipulations for a healthy and disciplined body, writing in 1903 that

[a] prominent foreigner declares that we squander as much energy as most other nations utilize. Speaking of this, one had well said [sic]: "If one observes a crowd, it is curious and disagreeable to see how few there are who are not constantly making grimaces and working their faces and jaws in some manner. . . it is misdirected nervous energy, which ought to be aiding the movements of the legs or getting stored up somewhere in the central reservoirs for future use." 66

If the model and ideals embodied by the YMCA were understood to be applicable to the men of any culture, this was only true insofar as those men could shake off the corporeal shackles of premodernity and begin understanding and disciplining the condition and motions of their own bodies.

But this improvement was not something that young Chinese men could just do on their own; they had to be supervised by properly experienced authorities on the subject of the body and sport. As sports continued to catch on in the earliest years of the Republic, J. H. Crocker, National YMCA Physical Director, wrote of the "danger" posed by inexperienced native physical education instructors: "Chinese students who have attended some foreign college for one or two years, and taken an interest in athletics, are offering their services as physical directors-and being accepted. This kind of supervision is bound to bring trouble." 67

It was also important how, not only by whom, these lessons of physical fitness were taught. The model by which the healthy Christian self could be built was a proven one, and the missionaries would tolerate no short-sighted deviance from it. In 1909, one observer wrote: 
[T] here is noticeable a tendency in China to change the old list of track and field sports as recognised in nearly all Western lands and of introducing "freak" events, such as pie races and potato races. These changes are to be regretted. . . . For the recognised list has been worked out by long experience, and includes, in well balanced proportions for the different parts of the body, events requiring skill, agility and endurance. A pie race requires rather capacity and appetite! Moreover, the recognised events can be judged, and comparisons be made with records accomplished at other times and places. No one can compare the records of pie races a thousand years ago or a thousand miles away, with pie races today! It will be time enough when we in China have equalled the records of all other countries in these matters to introduce improvements then. ${ }^{68}$

Theirs was truly a program of normalization-by its very nature a project that would not sanction the least variation from the tried and true motions, routines, and rhythms. This is not to label all YMCA personnel as bigots unable to accept local forms or flavor. In 1916, YMCA inspectors praised a local athletic club for including "Chinese exercise" programs every morning as a way to attract older Chinese men into the gym. ${ }^{69}$ But when it came to the unity and sanctity of Western sport and fitness, local autonomy and input were simply not negotiable items.

This goal of bringing Chinese men and their nation into the Western and modern fold can be seen in the very terms used to motivate those young men participating in the YMCA athletic programs. As early as 1907, the Tianjin YMCA widely propagated a slogan, said by $\mathrm{C}$. H. Robertson to "grip in a remarkable way the heart and imagination of Chinese officials, educators, and students." It consisted of three simple but weighty questions:

1. When will China be able to send a winning athlete to the Olympic contests?

2. When will China be able to send a winning team to the Olympic contests?

3. When will China be able to invite all the world to come to Peking for an International Olympic contest, alternating with those at Athens? ${ }^{70}$

Robertson, an amazing man who combined athletic and scientific prowess, missionizing zeal, and fascination with Chinese language and education, also made several presentations in 1908 showing slides from that year's London Olympics on his new "projectoscope." 71 This heady Olympic talk is a fine indication of just how thoroughly YMCA leaders wanted to integrate China into the club of strong and healthy nations. The Olympics were not for weaklings, and as the Chinese learned a quarter of a century later when they did begin sending representatives to the Olympic Games, participation in this holy international realm was a very meaningful statement about the state of one's nation. These missionaries wanted the best for the Chinese nation (especially achievements that would reflect favorably on their work as well), and slogans like the one cited above explain clearly on whose terms this success was to be achieved.

The YMCA's early work in spreading physical culture in China's cities was quite successful. Official statistics from the Tianjin Association show "participation" (calculated in person-days) of 33,020 in 1907, 35,668 in 1909, and 44,096 in 1910 . These numbers surely have to be taken with a mine of salt. For 
example, in 1909, the twelve tennis enthusiasts who played on YMCA courts were each counted 144 times. The fifty regular participants in morning calisthenics were each counted 168 times. The 1909 total also included the roughly seven thousand spectators who attended the Seventh Annual Tianjin Athletic Contest. But the 18,540 reported under "Regular Work, Athletic Field," even if consisting only of diehards who came out to the YMCA three times a week, would still represent a group of over one hundred new-minded athletes. ${ }^{72} \mathrm{Be}-$ sides these regular classes, the Tianjin YMCA sponsored, beginning in 1903, annual athletic meets featuring schools from Tianjin and Hebei Province. Starting in 1909, the YMCA also organized a Tientsin (Tianjin) Interscholastic Basket-ball Association and Tientsin Interscholastic Foot-ball League. ${ }^{73}$ By the time of the Revolution of 1911, YMCA physical educators felt quite confident of the implications of their work upon the collective psyche of China's youth and the future of the nation.

However, the YMCA's great headway in spreading the fruits of physical fitness does not represent unanimous acceptance or participation by the Chinese populace that they had taken as their pupils. An embarrassing and potentially damaging moment came early in the Tianjin YMCA sporting enterprise, when a frustrated soccer coach wrote in Tientsin Young Men,

We are sorry that two of our strongest football players, Mr. Yang I and Mr. J. S. Chuan, have resigned from the [Association] team. Both have received letters from their parents forbidding them to play football. We appreciate the feeling of the parents thus displayed but how are they going to keep their sons off bicycles, iceponds, horseback riding all of which are accompanied with more or less of danger. Better let the boys play these games and get used to hard knocks. ${ }^{74}$

If the bodies of China's men were to overcome their nation's legacies of weakness, this regressive and overcautious family meddling would simply have to stop; one can easily imagine this coach cursing the fates that gave him such mamas' boys for star players. But in his sarcastic response to these concerned families, the missionary clearly overstepped his bounds. Just a week later, Tientsin Young Men was forced to print a humbling (if stubborn) retraction:

We should just like to say by way of further explanation that we mean no disparagement to [I's and Chuan's] parents who have the perfect right to do what they did and their sons should obey them. The point of our remark was that football was not exceptional in its liability to injury from other sports in which young men like to engage and that it is difficult for parents to shut their boys off from all forms of other sports and at the same time expect them to be sturdy, ambitious, successful men in the world of affairs. ${ }^{75}$

If its leaders hoped to make any headway with these novel and strange new sporting forms, the YMCA could not afford to make enemies of the perhaps influential Tianjin families critiqued and evaluated here.

Not all of China, or even all of Tianjin, was ready for this doctrine that equated taking "hard knocks" in sometimes violent sport with one's future scholastic, financial, moral, or national success. Nor is it a fantastic stretch to imagine 
in other terms these families' reluctance to see their sons take these beatings, perhaps as a type of resistance to the larger "knocks" given China by the imperialist powers which the YMCA represented. Records kept by the YMCA in China do not catalog all the ways in which local populations tried to resist or subvert the organization's powerful program. Therefore, it is important to recognize and examine these smaller expressions of dissent and improvisationeven down to a heretic Chinese convert's use of "freak" events like a pie race instead of the proper and "proven" Christian sports regimen.

It is for these reasons that this description of YMCA efforts is not fashioned as a simple narrative of progress-sporting, spiritual, or otherwise. The organization's endeavor to remake China in its own image was obviously never a realistic goal. However, in terms of modern Chinese physical culture, it would be very unwise to underestimate YMCA influence. Before long at all, the forms they worked so hard to spread in urban centers like Tianjin and Shanghai quickly spread to much farther reaches of China. In these areas, the calisthenicsbased programs of the late Qing educational reforms were soon transformed by these more exciting and authentically "national" sporting forms.

RAH, DRAGON, SIS, BOOM, AH: THE FIRST NATIONAL GAMES, 1910

The first decade of the new century ended with a bang as events brought modern physical culture into national focus for the first time. I have already discussed the many developments in Chinese modern physical culture which, even if aiming for a strong Chinese nation, still took as a working domain only their own immediate urban regions. Thus, perhaps in these uncertain times, it took the wide-eyed activists of the YMCA to see China as a viable unit, to dare to organize an athletic meet which would bring together skilled and motivated men from all over (the eastern urban half of) China to push each other to be the best they could be. Perhaps only the charges of the YMCA, sure of themselves and their nation-based perspective (that is, a perspective which envisioned regions only in terms of the universalizing form of the "nation-state"), dared to believe that a national future was truly viable for China. And perhaps only they dared to cooperate with the bureaucrats of the aging Qing Dynasty in running a national athletic meet that held such hope for a new national form for China.

In 1909, Shanghai YMCA Physical Director M. J. Exner excitedly reported that:

We have a movement on foot to run some national athletic meets in connection with the National Industrial Exposition to be opened in Nanking next May. . . . It will be a great opportunity to advance physical training, it will make the Association prominent and it will be wholesome to Christianity to be allied with the promotion of so practical a philanthropic movement. ${ }^{76}$

Exner's negotiations with Zhejiang-Jiangsu Governor-General Duan-fang, his successor Zhang Renjun, and industrialist Zhang Jian paid off. ${ }^{77}$ China's first national meet (called the Quanguo Xuexiao Qufendui Di Yi Ci Tiyu Tongmenghui, 
or the First National Athletic Alliance of Regional Student Teams) was soon scheduled for inclusion in the Nanyang Industrial Exposition, to be held in Nanjing in October $1910 .{ }^{78}$ The exposition, a great celebration of and monument to the construction of a capitalist economy, a capitalist labor discipline, and a modern ethos of production and consumption in China, seemed the perfect moment for such a breakthrough in Chinese national strength, modernity, and integration.

The meet would be made up of three different components-intercollegiate, middle school, and sectional at-large competitions - and would feature athletes from five regions: North China (Huabei), South China (Huanan), Wuhan, Shanghai, and Nanjing/Suzhou (Wuning). Each area held a selection meet to determine who would have the honor of representing their home region in Nanjing. The North China Qualifying Meet was held in Tianjin, with twenty athletes selected to the team by the Northern Athletic Committee. ${ }^{79}$ Days later, two hundred students from the five Tianjin schools represented on the North China team gathered at the YMCA to send off their athletic classmates in rousing fashion. One of the missionaries in attendance wrote:

After the speeches the Tungchou and Putung boys each sang their school songs. ... The Putung School cheer,

"Rah, Rah, Rah,

Dragon, Dragon, Dragon, Sis, Sis, Sis,

Boom, Boom, Boom, $\mathrm{Ah}, \mathrm{Ah}, \mathrm{Ah}$,

Putung, Putung, Putung,"

was revised to meet the need of a North China cheer. The word "Putung" at the end was changed to "North China," and after a brief practice the students of the five institutions united in giving such a cheer as old Tientsin had never heard before. ${ }^{80}$

This report is a perfect demonstration of the important trend, present in almost any sports-related source of the times, to draw attention to the notions of regional or even national unity (against the harsh realities of local, provincial, or regional rivalry and strife). There is little question that the energetic missionaries of the YMCA sought to remake their young Qing "Dragon" subjects in their own image, as spirited college or prep school men - the men who, as in so many other nations, would be trusted with national and commercial affairs in the exciting and intimidating new twentieth century.

Indeed, it is no coincidence that the North China Herald commented that "The first National Athletic Meeting in China bids fair to leave as significant a mark on the country as the meeting of the National Assembly in Peking." Hugh Moran, a YMCA man based in Hankou, concurred with this judgment, commenting that

it is a significant fact that, while the Senators were for the first time matching their wits in Peking, the school boys were first measuring their wind in the Southern Capital. Had either event taken place without the other, it would have shown to those who see deeply into the affairs of the nation, a serious defect in her well-rounded development. ${ }^{81}$ 
Norbert Elias has written about the "not accidental" affinity between sports and parliamentary government, seeing an important intersection between the sporting and parliamentary faiths in victory by rational rule rather than by violence. ${ }^{82}$ That these foreign observers in 1910 China saw these connections as so commonsensical is surely testament to the magnitude of the impact the Westerners hoped to make on China.

While the YMCA made these plans and dreamed these dreams about their influence on the Chinese nation, Shanghai's daily Shenbao got in on the exciting and profitable action as well. The week before the exposition, Shenbao posted daily information about the coming games, welcoming the 140 participating athletes from all around China, ${ }^{83}$ listing daily event schedules, and announcing the good news that admission to all the athletic events would be included in the price of the Industrial Exposition ticket. ${ }^{84}$

There are only scattered records left of this first Chinese national meet; Shenbao's updates end after the first day of competition. In 1910, an athletic meet was perhaps seen as an important event to announce beforehand, but not necessarily to describe afterwards (despite a total attendance of some forty thousand people). The importance was not in who won or by how much, but in the fact that the meet was happening, and that it was apparent to all as a very visible sign of national and masculine progress. Almost all records of these first national games come from accounts written by excited YMCA personnel proud of the spirit and initiative shown by their athletes in Nanjing.

These reports are devoted almost solely to descriptions of the character and "clean, strong self-reliant manhood" that made a Christian China seem like such a realistic goal for YMCA personnel. The YMCA magazine Association Men reported "monster gatherings" at the meet's basketball and soccer games, and a first-day crowd of "16,000, mostly college boys." 85 M. J. Exner was also impressed by the presence of Nanjing, Shanghai, and Suzhou college students, who had been given one week's holiday to attend the meet, and their "enthusiasm expressed in college cheers and songs . . . just such as we should expect to see on a similar occasion in America." He commented on the "breaking down of sectional feeling," and the "manhood[, and t]he spirit of true sportsmanship, of fairness, of honesty and honor" which the Games demonstrated.

Most of all, Exner appreciated the meet's usefulness in questioning the "popular conception of a Chinese scholar . . . that of a man with a great head, emaciated body and hollow chest, sitting and contemplating; solving the problems of life by thinking, dissociated from doing." 86 Fong F. Sec, a Chinese convert and future chairman of the YMCA National Committee, also showed his appreciation in similar self-Orientalizing terms:

Those sturdy athletes, wearing spikes and running gear, as they strained every nerve and grit their teeth in order to win honors for their college or section, formed a strong contrast to the gentlemen with long finger-nails, large goggles, and round shoulders-the typical Chinese scholar of the old school. ${ }^{87}$ 
Several observers commented on another "pleasing feature" of the Games which accentuated even more the manliness of these sturdy athletes - "the presence of the hundreds of ladies at the games." 88 Michael Oriard has written on the type, developed in the American press of the 1880s and '90s, of the female football fan, a woman unafraid to show her admiration for male athletic prowess. Oriard describes how, in light of the New Woman and her challenges to conventional gender roles, this narrative "accommodated women's sexuality to a conventional male-female relationship." ${ }^{89}$ Writings on this first Chinese national meet can surely be understood to serve the same gendering purpose. This take on the women's presence in the audience, a presence that surely could have been interpreted in other and more dangerous ways, affirmed a female passive nature that many men hoped to believe in. It also served to further gender the male athletes of the games: their heroic sporting and national achievements could only truly be so when performed before an audience of female spectators supposedly swooning over these strong men of the new China.

To many, the most powerful symbol of the obstacles blocking the development of a strong and masculine China was the queue, the humiliating "pigtail" which the Manchu regime mandated all male subjects to wear. The menace posed by the "feminine" queue to modern athletic participation was hardly limited to symbolism. As M. J. Exner explained:

Wherever athletes go the queue falls into disfavor because of the hindrance it presents. In the gymnasium especially, many vicious jerks of the head are occasioned on account of the queues being wrapped around the bars or catching on parts of the apparatus or being stepped on by a fellow gymnast.

It is hard to tell which considerations-practical or symbolic-mattered most to the queued athlete of the late Qing era. Yet the athletic experience seemed to present the perfect justification for shearing away this unwanted hair. Remarkably, eight athletes on the North China team felt so liberated by their upcoming participation in the national meet held in the old capital of the fallen Ming Dynasty, Nanjing, that they cut off their queues during their voyage. ${ }^{90}$

Then there was Sun Baoxin of Tianjin, a standout student (fourth in his Putong Academy class) and, as the holder of six North China athletic records, one of the finest athletes in all of the Qing empire. 91 "On account of opposition from his family," Sun could not convince himself to join his dangerously committed teammates in liberating his head and mind of this symbol of Manchu rule. This hesitation would cost Sun days later. On the first day of the meet, after finishing a close second place in the shotput competition, Sun faced tough challengers from Shanghai and Nanjing in the high jump competition. When it came his turn, athletic tragedy struck. Sun's strenuous jump was enough to clear the bar, but his long swinging queue knocked the bar to the ground. Encouraged by a meet official who barked at the disappointed Sun, "Cut it off at once!" Sun took the drastic step that he had once feared. Now, with victory and national fame on the line, Sun "hacked his queue off that night, with the declaration that the 
next day he would jump higher than any one [sic] ever jumped before in China. He made good on his boast, setting the excellent mark for future competitors of $5 \mathrm{ft}$. 53/4 in." 92 Buoyed by this newfound manhood and desire, Sun went on to win seven medals for North China and the Tianjin YMCA, ${ }^{93}$ making his name as a true pioneer of Chinese masculinity and modernity.

Allegory as history surely has its limits. Any effort to take Sun's efforts as representative of some single bounded process - the transition of the Chinese people from empire to nation, for example-would be simply ahistorical. Clearly, the significance of these first Chinese national games is centered more in the real nationizing experiences shared by the spectators, officials, and athletes than in our interpretations of Sun's performance, eighty years after the fact. That said, however, there hardly could be a finer, more appropriate, or more inspiring allegory of the drive, the initiative, and the personal and national tensions of this new sports physical culture than Sun's incredible steps and leaps in Nanjing.

\section{CONCLUSION}

The history of China's exposure to modern physical culture is a somewhat sensitive topic in contemporary times; the explicit nationalism of contemporary Chinese sport leaves little room for the complexity of its imperialist introduction to China. The 1987 film Soccer Heroes, directed by Xie Hong, was one attempt to resolve these contradictions. In this film, a bunch of lovable teahouse ne'er-do-wells happen upon a soccer game between two British teams in postBoxer Uprising Beijing. After the game, the British players, led by Harley, captain of the Pirates, curse this handful of Chinese spectators and kick dozens of soccer balls at them. The foreign soccer fans in attendance all laugh and cheer, a British official in attendance toasts Harley for this display, and the Chinese victims swear revenge.

They organize their own soccer team, the Dragons, made up of shuttlecock and martial arts performers from the streets of Beijing, and even prisoners of the Manchu regime. Sweet revenge comes when the Dragons beat the British Pirates by a score of 10 to 9, and the once-villainous Harley declares that he respects the Chinese players and wants to be friends. Victory is short-lived, however, as Manchu officials, ignorant and/or contemptuous of the significance of this victory for the Han people, arrest several of the Dragon players and sentence them to death. ${ }^{94}$ In their martyrdom, these "soccer heroes" are anything but dupes of Western sporting "cultural imperialism." Instead, their proudly indigenous and racial-revolutionary adaptation of modern soccer is meant to signify a double victory over the forces of foreign imperialism and Manchu brutality that supposedly combined to suppress the Han Chinese spirit for so long.

The details of Xie Hong's film account are dubious at best. But the conversion, illustrated in Soccer Heroes, of shuttlecock and martial arts performers into soccer players is an important image. The modern forms and notions of 
physical fitness, strength, and physical culture rendered virtually all of the diverse forms of Chinese physical culture obsolete by the last decades of the nineteenth century, and relegated them to history. With the exception of the martial arts genres kept alive by proud nationalist activists and those few games that were dubbed "traditional" and maintained as quaint Oriental living relics, polite society and the national realm were now the domain of these modern sporting forms.

The traditional physical pursuits, for all that they meant to Chinese culture over so many millennia, did little to prepare China for the modern types and notions of physical culture introduced in the late Qing. The tiyu sports (and the ticao gymnastics and calisthenics) born of the imperialist mind and project represented ideologies that had no true precedent in Chinese thought or culture. Not only were these ideas not in the same ballpark as the traditional forms, as it has been said, but they were a different sport altogether.

The philosophical turns taken in the years immediately following the disastrous Sino-Japanese War of 1894-95 created a space into which these Western sporting forms could fit quite comfortably. Rooted in Social Darwinian and Spencerian notions of the healthy well-rounded body and its place in society, these sports worked perfectly in a China searching for competitive and martial modes by which to train their beaten bodies and spirits. The spread of these sports was restricted almost exclusively to China's urban settings, as they were during most of the Republican period. Yet it was quite easy for the young athletes of these cities to imagine and believe firmly in the power of their bodily motions to finally move China's four hundred millions and create for all of them a new and bright national future.

NOTES

1. Caspar Whitney, "Non-Athletic China," Harper's Weekly 42, No. 2148 (19 February 1898), 189.

2. Phillip Whitten, "Strong-Arm Tactic," The New Republic, 17 November 1997, 12.

3. Ouyang Liqiang, "Jiaguwen Zhong de Tiyu Huodong" [Physical Culture Activities as Seen in Oracle Bones], Tiyu Wenshi [Sport History] 57 (20 September 1992), 33 $34,40$.

4. The study of what is called "ancient physical culture" (gudai tiyu) took off in China in the early 1980s and is a thriving industry today. I personally find it hard to use this term to describe a single identifiable "ancient tiyu," since the premodern period offers no analog to the totalizing modern physical culture introduced to China in the late nineteenth century as part of the modern world system of nation-states.

Still, the dozens of scholars-almost exclusively based in the PRC and trained in physical education and ancient Chinese literature or history-working in the "ancient physical culture" field have uncovered wonderful histories of these physical forms. Particularly useful are the following works: Lin Boyuan, Zhongguo Wushu Shi [The History of Chinese Martial Arts] (Taibei: Wuzhou Chubanshe, 1996); Ren Hai, Zhongguo Gudai Tiyu [Ancient Chinese Physical Culture] (Taibei: Taiwan Shangwu Yinshuguan, 1994); Guojia Tiwei Tiyu Wenshi Gongzuo Weiyuanhui [National Physical Culture Commission, Committee on Sports History Research] and Zhongguo Tiyushi Xuehui 
[Chinese Sports History Association], eds., Zhongguo Gudai Tiyushi [The History of Ancient Chinese Physical Culture] (Beijing: Beijing Tiyu Xueyuan Chubanshe, 1990); Sheng Qi and Ding Zhiming, Zhongguo Chuantong Tiyu Fengsu [Forms and Practices of Traditional Chinese Physical Culture] (Taibei: Baiguan Chubanshe, 1994); and several works by Weng Shixun on the history of soccer and polo in China, such as "'Lian pian ji ju rang' Shuo de Shi Maqiu" [What the References to "swiftly hitting the ball into earthen mounds" Refer to is Polo], Tiyu Wenshi 18 (1986), 19-20; and "Shilun Handai Zuqiu - jian Da Liu Bingguo Laoshi" [A Discussion of Han Dynasty Soccer-and an Answer to Professor Liu Bingguo], Tiyu Wenshi 35 (January 1989), 44-55.

5. Allen Guttmann, Games and Empires: Modern Sports and Cultural Imperialism (New York: Columbia University Press, 1994), 6-11, 184-88.

In the China field, Fan Hong's work is one example of the modernist "liberatory" perspective that Guttmann proposes. For Fan, who studies women's physical culture, the "essential point [is] that the pursuit of physical freedom was an integral part of women's emancipation in China." Fan Hong, Footbinding, Feminism and Freedom: The Liberation of Women's Bodies in Modern China (Portland, OR: Frank Cass, 1997), 137. This line is similar to that formulated by an official state history of Chinese sports and physical culture, which describes the process of Chinese women "gallantly ascending the stage of history" via their participation in team sports. Guojia Tiwei Tiyu Wenshi Gongzuo Weiyuanhui and Zhongguo Tiyushi Xuehui, eds., Zhongguo Jindai Tiyushi [The History of Modern Chinese Sport] (Beijing: Beijing Tiyu Xueyuan Chubanshe, 1989), 176.

6. For example, see Li Ning, "Wan Qing Jundui Bianlian yu Jindai Tiyu Chuanbo" [Late Qing Military Training and the Spread of Modern Physical Culture], Tiyu Wenshi [Sport History] 7 (June 1984), 7; Guojia Tiwei Tiyu Wenshi Gongzuo Weiyuanhui and Zhongguo Tiyushi Xuehui, eds., Zhongguo Jindai Tiyushi, 53-55.

7. Angela Zito, "Silk and Skin: Significant Boundaries," in Angela Zito and Tani E. Barlow, eds., Body, Subject \& Power in China (Chicago: The University of Chicago Press, 1994), 105, 117.

8. Benjamin A. Elman, From Philosophy to Philology: Intellectual and Social Aspects of Change in Late Imperial China (Cambridge, MA: Council on East Asian Studies, Harvard University, 1984), 236-41; Benjamin Schwartz, In Search of Wealth and Power: Yen Fu and the West (New York: Harper \& Row, 1964), 6-8.

9. Mary C. Wright, The Last Stand of Chinese Conservatism: The T'ung-Chih Restoration, 1862-1874 (Stanford: Stanford University Press, 1957), 2-8, 43-67.

10. Schwartz, In Search of Wealth and Power, 12-17.

11. James Pusey makes the point that although 1860s self-strengtheners like Feng Guifen did not need Darwin to understand Western intentions and the source of these nations' strength, it was Darwin, as "translated" by Spencer, that allowed Yan Fu to bring in biology and physical strength, and to proclaim that (in Pusey's words) "they who make themselves fit survive." James Reeve Pusey, China and Charles Darwin (Cambridge, MA: Council on East Asian Studies, Harvard University, 1983), 6, 50-79.

12. Hsu I-hsiung, "Zhongguo Jindai Minzu Zhuyi Tiyu Sixiang zhi Tezhi" [Special Characteristics of Modern Chinese Nationalistic Philosophies of Physical Culture], Tiyu Xuebao (Bulletin of Physical Education) 12 (December 1990), 15.

13. Schwartz, In Search of Wealth and Power, 54-59.

14. Private conversation with Munakata Tatsuya, Taipei, Taiwan, 21 December 1995; Private conversation with Inoue Akio and Abe Ikuo, Shunde, Guangdong Province, China, 21 September 1996.

15. Yan Fu, "Yuan Qiang Xiudinggao" [On Strength: A Revised Draft], in Wang Shi, ed., Yan Fu Ji, Di Yi Ce [Yan Fu's Writings, Volume 1] (Beijing: Zhonghua Shuju, 1986), 27. 
16. Hao Chang, Chinese Intellectuals in Crisis: Search for Order and Meaning (1890-1911) (Berkeley: University of California Press, 1987), 92-7.

17. Tan Sitong, "Renxue, Juan Shang" [A Study of Humanity, Part 1], in Tan Sitong Quanji [Complete Collection of Tan Sitong's Writings] (Beijing: Sanlian Shudian, 1954), 37.

18. Liang Qichao, "Xinmin Shuo, Di Shiqi Jie: Lun Shangwu" [On the New Citizen, Chapter 17: On Martial Spirit], in Liang Qichao, Yinbingshi Heji, Zhuanji Di San Ce [A Collection from the Ice-drinker's Studio: Commentaries, Volume 3] (Shanghai: Zhonghua Shuju), 108-9.

19. Liang Qichao, "Xinmin Shuo Shi" [On the New Citizen, Part 10], Xinmin Congbao [New Citizen] 2 (1902), 47.

20. Liang Qichao, "Xinmin Shuo, Di Shiqi Jie: Lun Shangwu," 117.

21. Fenhesheng (Cai E's pen name, meaning "Student Raising his Wings"), "Jun Guomin Pian (xu Di Yi Hao)" [On Militarized Citizenship, continued from Issue 1], Xinmin Congbao [New Citizen] 3 (1/2/Guangxu Year 28, or 10 March 1902), 68.

22. Fenhesheng, "Jun Guomin Pian" [On Militarized Citizenship], Xinmin Congbao [New Citizen] 1 (1/1/Guangxu Year 28, or 8 February 1902), 83.

23. Fenhesheng, "Jun Guomin Pian (xu Di Yi Hao)," 69.

24. (Jiang) Baili, "Jun Guomin zhi Jiaoyu" [Militarized Citizenship Education], Xinmin Congbao [New Citizen] 22 (15/11/Guangxu Year 28, or 14 December 1902), 345 .

25. (Jiang) Baili, "Jun Guomin zhi Jiaoyu," 41-4.

26. Hsu I-hsiung, "Qingmo Minchu Junguomin Jiaoyu Tiyu Sixiang de Xingcheng (Xia)" [The Formation of Late Qing-Early Republican Militarized Citizenship Physical Education Thought, Part 2], Guomin Tiyu Jikan [Physical Education Quarterly] 20 (December 1991), 68-9.

27. Wang Gungwu and Aihwa Ong use similar translations for minzu, but without significant explanation. Wang discusses the "nation-race" with regard to Sun Yat-sen's use of the term. Wang Gungwu, China and the Chinese Overseas (Singapore: Times Academic Press, 1991), 200-1. Ong, in her theorizing of contemporary nationalism, writes on "the racial and cultural exclusivity of the minzu (race/nation) that cuts across class differences." Aihwa Ong, Flexible Citizenship: The Cultural Logics of Transnationality (Durham: Duke University Press, 1999), 56.

28. Frank Dikötter, The Discourse of Race in Modern China (Stanford: Stanford University Press, 1992), 108-9.

29. Yan glossed jin-meng-na-zhi-an as "physical training facility" (lianshenyuan). Yan Fu, "Yuan Qiang Xiudinggao," 132.

30. Liang Qichao, "Xinmin Shuo, Di Shiqi Jie: Lun Shangwu," 108-9; Pusey, China and Charles Darwin, 263-5.

31. Liang Qichao, "Xinmin Shuo, Di Shiqi Jie: Lun Shangwu," 117.

32. Dorothy Ko, "The Body as Attire: The Shifting Meanings of Footbinding in Seventeenth-Century China," Journal of Women's History 8 (Winter 1997), 9.

33. Dorothy Ko, "Footbinding as Female Inscription," unpublished paper presented at the Conference on Women in Confucian Cultures in Pre-modern China, Korea, and Japan, 28 June-1 July 1996, La Jolla, California, 3.

34. Zhu Zhuang, "Lun Zhongguo Nüxue Buxing zhi Hai" [On the Harm Done by Stagnancy in Women's Education], Nüzi Shijie [Women's World] 3, reprinted in Li Yuning and Chang Yü-fa, eds., Jindai Zhongguo Nüquan Yundong Shiliao, 1842-1911, Shang Ce [Documents on the Feminist Movement in Modern China, 1842-1911, Volume 1] (Taibei: Zhuanji Wenxue She, 1975), 639.

35. Lianshi (pen name, meaning "Tempered Stone"), "Benbao Wu Da Zhuyi Yanshuo" [Discourse on the Five Guiding Principles of Our Publication], Zhongguo Xin 
Nüjie Zazhi [New Chinese Woman] 2-4 (1907), reprinted in Li Yu-ning and Chang Yüfa, eds., Jindai Zhongguo Nüquan Yundong Shiliao, 1842-1911, Xia Ce [Documents on the Feminist Movement in Modern China, 1842-1911, Volume 2] (Taibei: Zhuanji Wenxue She, 1975), 783-4.

One scholar identifies a Japanese columnist named Kikui, writing in 1901, as the first to use this humiliating term "Sick Man of the Orient," although Yan Fu and Kang Youwei both used terms like "afflicted" (bingzhe) or "affliction" (bingzheng) to describe China's weak populace. Tan Huawen, "'Dongya Bingfu' Xiaoshi” [A Brief History of the Term "Sick Man of the Orient"], Tiyu Wenshi [Sport History] 17 (April 1986), 48.

36. Yuan Shikai, "Nüzi Wei Guomin zhi Mu" [Women are the Mothers of Citizens], Shuntian Shibao [Shuntian Prefecture Times], 17/6/Guangxu Year 31 (19 July 1905), reprinted in Li and Chang, eds., Nüquan Yundong Shiliao, Shang Ce, 606-8.

A similar and perhaps related Meiji-era Japanese formulation praised responsible, national-minded women as gunkoku no haha, or "mothers of the military nation."

37. "Zhi Fu Yundonghui Shi" [Record of My Attendance at the Athletic Meet], Minxu Ribao [Sigh of the People], 1 November 1909, reprinted in Li and Chang, eds., Nüquan Yundong Shiliao, Xia Ce, 1206-8.

38. Julie Broadwin has explained that boundfoot women came to be seen as perhaps China's worst enemies, since their condition could be blamed for a Chinese lack of production and military strength, as well as for an abundance of laziness and irrational eroticism. Julie Broadwin, "Walking Contradictions: Chinese Women Unbound at the Turn of the Century," Journal of Historical Sociology 10 (December 1997), 427.

39. "Youxi zhi Weisheng shang Jiazhi" [The Value of Games with Regard to Hygiene], Jiaoyu Zazhi [The Chinese Educational Review] 2 (10/7/Xuantong Year 2, or 14 August 1910), 46.

40. Tani E. Barlow, "Theorizing Woman: Funü, Guojia, Jiating [Chinese Woman, Chinese State, Chinese Family]," in Zito and Barlow, eds., Body, Subject \& Power in China, 253.

41. "Xuanze Ticao Youxi Jiaocai zhi Fangzhen" [Directions to Consider When Designing a Curriculum of Calisthenics and Games], Jiaoyu Zazhi [The Chinese Educational Review] 2 (10/10/Xuantong Year 2, or 11 November 1910), 123.

42. Itô Yonejirô, translated by Cai Wensen, "Xiaoxuexiao Nannü Ertong Xinshen zhi Chabie" [The Psychological and Physical Differences between Elementary Boy and Girl Students], Jiaoyu Zazhi [The Chinese Educational Review] 2 (10/11/Xuantong Year 2, or 11 December 1910), 152.

43. Yuanhu Tongding Nüshi, (pen name, meaning "Pained Woman from Yuanhu"), "Chanzu Lun" [On Footbinding], Wanguo Gongbao [A Review of the Times], 26 (1896), 16219.

44. Xiaomei Chen, Occidentalism: A Theory of Counter-Discourse in Post-Mao China (New York: Oxford University Press, 1995), 5.

45. Chen, Occidentalism, 8.

46. Yuanhu Tongding Nüshi, "Chanzu Lun," 16219.

47. Chen Xiefen, "Lun Nüzi Yi Jiang Tiyu" [Physical Fitness Is Appropriate to Any Discussion of Women], Nüxuebao [Women Studies] 2(1903), reprinted in Li and Chang, eds., Nüquan Yundong Shiliao, Shang Ce, 574.

48. This line of argument can be seen most strongly in the writings of the revolutionary martyr Qiu Jin. Qiu, a martial arts aficionado and founder of the Shaoxing Women's Physical Education Association, also wrote very forcefully on the connections between strong, liberated women and a viable nation. Qiu used a similar line on the primacy of mothers and education in home education, and also bitterly condemned "corrupt women" who did not make contributions to, or even understand the concept of, the nation. Qiu Jin, "Jinggao Wo Nüguomin Tongbao" [A Warning to My Fellow Female 
Citizens], Shuntian Shibao [Shuntian Prefecture Times], 10/4/Guangxu Year 32 (3 May 1906), reprinted in Li and Chang, eds., Nüquan Yundong Shiliao, Shang Ce, 425.

49. "Ji Shanghai Ge Xiao Yundonghui" [Records of Meets at Several Shanghai Schools], Jiaoyu Zazhi [The Chinese Educational Review] 3 (10/5/Xuantong Year 3, or 6 June 1911), 41.

50. "Athletics," Tientsin Young Men 5 (23 March 1906), 1. The several misspellings and missed punctuation are the original author's.

51. Wu Wenzhong, Zhongguo Tiyu Fazhan Shi [The History of the Development of Chinese Sport] (Taibei: Guoli Jiaoyu Ziliaoguan, 1981), 71; Chen Xianming, Liang Youde and Du Kehe, Zhongguo Bangqiu Yundongshi [The History of Baseball in China] (Wuhan: Wuhan Chubanshe, 1990), 7; Gao Zhengyuan, Dongsheng de Xuri: Zhonghua Bangqiu Fazhan Shi [Rising Sun in the East: The History of the Development of Chinese Baseball] (Taibei, 1994), 19-21; Zhan Deji, "Woguo Bangqiu Yundong de Fawei yu Zhanwang" [The Humble Beginnings and Future Hopes for Our Nation's Baseball Movement], Jiaoyu Ziliao Jikan [Education Materials Quarterly] 10 (June 1985), 434.

52. "The Athletes of China," China's Young Men 11 (15 June 1916), 524.

53. Li Cimin, "Meixian Zuqiu Yundong Shihua" [Stories from the History of the Soccer Movement in Meixian County], in Guangzhou Wenshi Ziliao Xuanji, Di Ershisi Ji [Selected Materials on the History of Guangzhou, Volume 24] (Guangzhou: Wenshi Ziliao Yanjiu Weiyuanhui, 1981), 164-5.

54. Wu Wenzhong, Zhongguo Tiyu Fazhan Shi, 69.

55. Reginald Horsman, Race and Manifest Destiny: The Origins of American Racial Anglo-Saxonism (Cambridge, MA: Harvard University Press, 1981), especially 287-9 on the mission to expand to Asia and China in particular. Jun Xing has characterized this mission in the more familiar terms of spreading the "social gospel." Jun Xing, Baptized in the Fire of Revolution: The American Social Gospel and the YMCA in China: 19191937 (Bethlehem, PA: Lehigh University Press, 1996), 13-15.

56. Horsman, Race and Manifest Destiny, 90.

57. Shirley S. Garrett, Social Reformers in Urban China: The Chinese Y.M.C.A., 1895-1926 (Cambridge, MA: Harvard University Press, 1970), 102.

58. Jiang Zhenhua and Wang Qionghua, "Jindai Tiyu zai Yunnan Zaoqi de Chuanbo" [The Early Spread of Modern Physical Culture in Yunnan], Yunnan Tiyu Wenshi [Yunnan Province Sports History] 14 (October 1992), 60.

59. Fujian Sheng Difangzhi Bianzuan Weiyuanhui, ed., Fujian Shengzhi: Tiyu Zhi [Fujian Provincial Gazetteer: Chronicle of Physical Culture] (Fuzhou: Fujian Renmin Chubanshe, 1993), 36, 147.

This process was not entirely smooth, however. During the late Qing period, Cora Coole, superintendent of Christian schools in Gutian, Fujian Province, made a presentation to classically-trained Chinese scholars on the benefits of physical education and recreation. Shocked, the teachers explained to Coole that "If this foreign Superintendent wants to see human beings run around the yard in shorts they would take up a collection and hire some chair coolies to run around for her amusement, but students-NO!" Arthur Braddan Coole, A Troubleshooter For God in China (Mission, KS: Inter-Collegiate Press, Inc., 1976), 28-9. The classical scholar's opposition to healthy sports is an old and common trope, but should be understood as more than just resistance to this particular form of modern physical culture. I read examples like this as signs of resistance to the homogenizing forces of the world system of nation-states, part of which these classical scholars correctly understood modern sport to be.

60. For a longer discussion of this topic, see Andrew Morris, Cultivating the National Body: A History of Physical Culture in Republican China (Ph.D. diss., University of California, San Diego, 1998), Chapter 1. 
61. On an important origin of this model of modern sports, see Michael Oriard's brilliant description of Walter Camp, "the King of American Football," and his "master metaphor for football . . . the hierarchically structured, efficiently run industrial corporation." Michael Oriard, Reading Football: How the Popular Press Created an American Spectacle (Chapel Hill: The University of North Carolina Press, 1993), 37, 43-6, 168-9.

62. M. J. Exner, "Physical Training for the Chinese," Tientsin Young Men 8 (1 May 1909), 2.

63. Annual Reports of the Foreign Secretaries of the International Committee, October 1, 1910 to September 30, 1911 (New York: International Committee of the YMCA, 1911).

64. Gael Graham has written on the implications of this missionary emphasis on "Christian manhood" and its effect on missionary education (and physical education in particular) for Chinese girls in the late Qing and the Republican period. Gael Graham, "Exercising Control: Sports and Physical Education in American Protestant Mission Schools in China, 1880-1930," Signs: Journal of Women in Culture and Society 20 (Autumn 1994), 23-48.

65. Exner, "Physical Training for the Chinese," 2.

66. "The Time for Recreation," Tientsin Young Men 2 (27 June 1903), 2.

67. Annual Reports of the Foreign Secretaries of the International Committee, October 1, 1913 to September 30, 1914 (New York: International Committee of the YMCA, 1914), 74.

68. Hugh A. Moran, "Right Ideals in Athletics," China's Young Men 4 (May 1909), 41-2.

69. Annual Reports of the Foreign Secretaries of the International Committee, October 1, 1915 to September 30, 1916 (New York: International Committee of the YMCA, 1916), 43.

70. Annual Reports of the Foreign Secretaries of the International Committee, October 1, 1909 to September 30, 1910 (New York: International Committee of the YMCA, 1910), 192; Annual Reports of the Foreign Secretaries of the International Committee, October 1, 1907 to September 30, 1908 (New York: International Committee of the YMCA, 1908), 163.

David Treadup, protagonist of John Hersey's novel The Call, mentions in his report to the International YMCA Committee in New York his use of these very same questions to motivate his students in the "Peikai Middle School" in Tianjin. Indeed, Robertson's strong physique, love of sports, scientific curiosity, and showmanship, as demonstrated in his series of scientific lectures in China, seem to have been the basis for Treadup's character. John Hersey, The Call (New York: Alfred A. Knopf, 1985), 190.

Zhang Boling, founder of the Nankai Middle School, great tiyu enthusiast and a close friend of Robertson, also wrote in 1907-8 in the YMCA publication Tientsin Young Men on his dream of a Chinese Olympic team. Chih-Kang Wu, The Influence of the YMCA on the Development of Physical Education in China (Ph.D. diss., University of Michigan, 1956), 106.

71. "The Sixth Annual Athletic Contest," Tientsin Young Men 7 (24 October 1908), $3-4$.

72. Twelfth Annual Report of the Tientsin Young Men's Christian Association (Tianjin, 1908), 9; Thirteenth Annual Report of the Tientsin Young Men's Christian Association (Tianjin, 1910), 5; Annual Report of the Tientsin Young Men's Christian Association (Tianjin, 1911), 2.

73. The TIBA included five school teams, and the TIFL nine. Tianjin Tongzhi: Tiyu Zhi [Overall Annals of Tianjin: Sports Volume] (Tianjin: Tianjin Shehui Kexueyuan Chubanshe, 1994), 303-305; Tientsin Young Men 8 (20 February 1909), 3-4; Tientsin Young Men 8 (30 October 1909), 3-4. 
74. Tientsin Young Men 2 (19 December 1903), 4.

75. Tientsin Young Men 2 (26 December 1903), 4.

76. Annual Reports of the Foreign Secretaries of the International Committee, October 1, 1908 to September 30, 1909 (New York: International Committee of the YMCA, 1909), 439.

77. Although the meet was mostly managed by YMCA personnel, YMCA and Exposition organizers did combine to form a sixteen-man national committee, "equally divided between Chinese and foreign members," to make all final decisions. Also, five regional subcommittees were established, each with "a good, live Young Men's Christian Association officer as chairman" to do publicity work and attract participants. H. A. Moran, "The Nanking Meet: The First National Athletic Sports in China," personal report, 24 December 1910; Annual Reports of the Foreign Secretaries of the International Committee, October 1, 1909 to September 30, 1910, 173.

78. Hao Gengsheng, Hao Gengsheng Huiyi Lu [Memoirs of Hao Gengsheng] (Taibei: Zhuanji Wenxue Chubanshe, 1969), 21; Wu Wenzhong, Zhongguo Tiyu Fazhan Shi, 77.

79. "The Autumn and Spring Athletic Program," Tientsin Young Men 9 (8 October 1910), 3.

80. "Farewell to the North China Team," Tientsin Young Men 9 (15 October 1910), $3-4$.

81. H. A. Moran, "The Nanking Meet."

82. Norbert Elias, "Introduction," in Norbert Elias and Eric Dunning, Quest For Excitement: Sport and Leisure in the Civilizing Process (Oxford: Basil Blackwell, 1986), $28-34$

83. North China sent twenty athletes, South China twenty-eight, Wuhan twenty-one, Nanjing-Suzhou thirty-one, and Shanghai forty.

84. Shenbao [Shanghai Times], 15 October 1910, section 1, p. 4; "Quanguo Da Yundonghui zhi Xiansheng" [Announcement of the National Games], Shenbao, 16 October 1910, section 2, p. 3; Shenbao, 19 October 1910, section 1, p. 3.

85. "China is Getting Athletic," Association Men 36 (March 1911), 243.

86. Annual Reports of the Foreign Secretaries of the International Committee, October 1, 1909 to September 30, 1910, 174-7.

87. Fong F. Sec, "The First National Athletic Meet," China's Young Men 6 (January 1911), 30.

88. Fong F. Sec, "The First National Athletic Meet," 32.

89. Oriard, Reading Football, 247-57.

90. Annual Reports of the Foreign Secretaries of the International Committee, October 1, 1909 to September 30, 1910, 176; Annual Reports of the Foreign Secretaries of the International Committee, October 1, 1908 to September 30, 1909, 437.

The queue is also significant in Chinese recollections of the meet. Xu Shaowu, who traveled with his parents from Huangmei in eastern Hubei Province to the Nanjing meet, described a soccer game between Soochow and Jinling Universities, with the players' queues swinging to and fro. Xu Shaowu, "Wo de Huiyi" [My Memoirs], in Zhongguo Tiyu Wenshi Ziliao Bianshen Weiyuanhui, eds. Tiyu Shiliao, Di Shi Ji [Materials on the History of Physical Culture, Volume 10] (Beijing: Renmin Tiyu Chubanshe, 1984), 79.

It is also important to note that the game of soccer was still new enough that people were not quite sure exactly what to call it. In one Shenbao article on the meet, it was referred to twice as cuqiu ("kick-ball", this $c u$ coming from cuju, an ancient Chinese game resembling soccer), and once as tiqiu (also "kick-ball"). Clearly, there is identification here of the new Western-style soccer as being at least somewhat related to the ancient cuju. "Quanguo Da Yundonghui zhi Xiansheng," section 2, p. 3. 
91. Sun held North China records in the hundred-yard dash (104/5 seconds), twelvepound shotput ( 34 feet 10 inches), sixteen-pound shotput (18 feet $1 / 2$ inch), discus (74 feet 8 inches), high jump ( 5 feet 5 inches), and broad jump (18 feet $91 / 2$ inches). Tientsin Young Men 9 (2 July 1910), 4; "North China Interscholastic Athletic Records," Tientsin Young Men 9 (2 July 1910), 4; "The Autumn and Spring Athletic Program," 2.

92. H. A. Moran, "The Nanking Meet: The First National Athletic Sports in China;" Annual Reports of the Foreign Secretaries of the International Committee, October 1, 1909 to September 30, 1910, 176; Wang Zhenya, Jiu Zhongguo Tiyu Jianwen [Glimpses of Physical Culture in the Old China] (Beijing: Renmin Tiyu Chubanshe, 1987), 136.

93. Two rounds of the competition used the region (North China, etc.) as the team unit, and one round divided competitors by their schools. Liang Tian, Zhongguo Tianjing Fazhan Jianshi [A Concise History of the Development of Track and Field in China] (Guangdong Tiyu Kexue Yanjiusuo and Guangdong Tiyu Wenshi Weiyuanhui, 1982), $12-4$.

94. Xie Hong, dir., Jingdu Qiuxia [Soccer Heroes] (Emei Dianying Zhipianchang, 1987).

This narrative is another perfect instance of the appropriateness of Xiaomei Chen's Occidentalism model, as the red-blooded Han Dragons' success is in their dissident challenge to the Manchu Qing regime via this Western form of soccer. 